Disclosure of Interests: Thomas Dörner Grant/research support from: Eli Lilly, Janssen, Roche, UCB Pharma, Consultant for: Eli Lilly, Janssen, Roche, UCB Pharma, Speakers bureau: Eli Lilly, Janssen, Yoshiya Tanaka Grant/research support from: Abbvie, Astellas, Bristol-Myers Squibb, Chugai, Daiichi-Sankyo, Eisai, Mitsubishi-Tanabe, MSD, Ono, Taisho-Toyama, Takeda, Speakers bureau: Abbvie, Asahi-kasei, Astellas, Bristol-Myers Squibb, Chugai, Daiichi-Sankyo, Eli Lilly, Eisai, Glaxo-Smithkline, Janssen, Mitsubishi-Tanabe, Novartis, Pfizer Japan Inc, Sanofi, Takeda, UCB, YL Biologics, Michelle A Petri Shareholder of: Pfizer, Merck, Grant/research support from: AstraZeneca, Exagen, Consultant for: Eli Lilly, GSK, Merck EMD Serono, Janssen, Amgen, Novartis,

Quintiles, Exagen, Inova Diagnostics, AstraZeneca, Blackrock,

Glenmark, UCB, and the Annenberg Center for Health Sciences, Josef S. Smolen Grant/research support from: AbbVie, Eli Lilly, Janssen, MSD, Pfizer Inc, Roche, Consultant for: AbbVie, Amgen, AstraZeneca, Astro, Celgene, Celtrion, Eli Lilly, GlaxoSmithKline, ILTOO, Janssen, Medimmune, MSD, Novartis-Sandoz, Pfizer Inc, Roche, Samsung, Sanofi, UCB, Speakers bureau: AbbVie, Amgen, AstraZeneca, Astro, Celgene, Celtrion, Eli Lilly, GlaxoSmithKline, ILTOO, Janssen, Medimmune, MSD, Novartis-Sandoz, Pfizer Inc, Roche, Samsung, Sanofi, UCB, Ernst Dow Shareholder of: Eli Lilly and Company, Employee of: Eli Lilly and Company, Richard E Higgs Shareholder of: Eli Lilly and Company, Employee of: Eli Lilly and Company, Guilherme Rocha Shareholder of: Eli Lilly and Company, Employee of: Eli Lilly and Company, Robert Benschop Shareholder of: Eli Lilly and Company, Employee of: Eli Lilly and Company, Maria Silk Shareholder of: Eli Lilly and Company, Employee of: Eli Lilly and Company, Stephanie de Bono Shareholder of: Eli Lilly and Company, Employee of: Eli Lilly and Company, Robert Hoffman Shareholder of: Eli Lilly and Company, Employee of: Eli Lilly and Company DOI: 10.1136/annrheumdis-2019-eular.620

\section{THU0213 TRAASVIR STUDY: THROMBOTIC MANIFESTATIONS IN ANTIPHOSPHOLIPID ANTIBODY TRANSIENT POSITIVITY RELATED TO VIRAL INFECTIONS:}

Enrique Esteve-Valverde ${ }^{1}$, Cristina Belizna ${ }^{2}$, Domingo Ruiz-Hidalgo ${ }^{3}$, Jaume Trapé I Pujol ${ }^{4}$, Anna Arnau Bartes ${ }^{5}$, Jaume Alijotas-Reig ${ }^{6} .{ }^{1}$ Internal Medicine Department, Althaia Healthcare University Network of Manresa, Systemic Autoimmune Disease Unit, Manresa, Barcelona, Spain; ${ }^{2}$ Vascular and Coagulation Department, University Hospital Angers, Angers, France; ${ }^{3}$ Internal Medicine Department, Althaia Healthcare University Network of Manresa, Universitat Autònoma Barcelona, Manresa, Barcelona, Spain; ${ }^{4}$ Department of Laboratory Medicine, Althaia Healthcare University Network of Manresa, Barcelona, Spain; ${ }^{5}$ Clinical Research Unit, Althaia Healthcare University Network of Manresa, Manresa, Barcelona, Spain; ${ }^{6}$ Systemic Autoimmune Disease Unit, Department of Internal Medicine, Vall d'Hebron University Hospital, Department of Medicine, Universitat Autonoma Barcelona, Barcelona, Spain

Background: The mollecular pathogenesis of antiphospholipid syndrome is complex (environmental triggers, predisposed individuals). Previous studies suggested that infection may lead to the development of transiently elevated non-thrombogenic aPL antibodies. However, there are increasing case reports of patients with viral infections who develop antiphospholipid antibodies and thromboembolic events.

Objectives: To evaluate the role of acute viral infections in the development of thrombotic events related to aPL transitory (or permanent) positivity.

Methods: We include patients with a current viral infection that was diagnosed before elevated aPL antibodies were identified. One positive laboratory test either $\mathrm{LA}, \mathrm{aCL}$, or anti $\beta 2 \mathrm{GPI}$ antibodies after a prior diagnosis of infection was required ( $<3$ months). Infection must be followed by thromboembolic manifestations (arterial or venous). A time frame of 3 months between infection diagnosis and recognition of aPL antibodies positivity was established. Normal PT and APTT test were observed in all previous patient's blood tests.

Results: From January 2014 to date we have collected 40 cases with a demonstrated acute virosis and an aPL positive result with a thrombotic manifestation. 9 cases (22.5\%) for Epstein-Barr virus, 17 cases (42.5\%) were positive for CMV, $8(20 \%)$ for Parvovirus B19, 3 cases were positive for Influenza A H1N1,3 for HIV, 1 for RSV, 1 for $\mathrm{HCV}$ and 1 case for Rotavirus. Lupus anticoagulant ( $L$ A) positivity was showed in 22 cases $(55 \%)$, 15 cases $(37.5 \%)$ tested positive for $\operatorname{lgM}$ anticardiolipin antibody and 13 cases (32.5\%) also tested positive for IgM anti- $\beta 2 \mathrm{GPI}$ antibodies. Unfortunately, anti-prothrombin antibodies could not been analysed. The clinical manifestations were: leg deep venous thrombosis (17 cases) (42.5\%), pulmonary embolism (5 cases) (12.5\%), superior limbs (3 cases) $(7.5 \%)$ livedoid vasculopathy (3 cases) $(7.5 \%)$, splenic infarction (1 case), ovarian venous thrombosis ( 1 case). Only four arterial thromboses were observed: superior limbs (2 cases), digital ischemia (1case) and transverse myelitis (1 case). We have observed how the IgM virus related antibody became negative and the aPL became negative in parallel in $20 / 40$ cases $(50 \%)$

Conclusion: We hypothesized that thrombotic manifestations of aPLrelated acute viral infections are underdiagnosed, and probably in predisposed host, some viral infections may induce the transient apparition of aPL, mainly those with LA activity with potential pathogenic thrombotic properties.

\section{REFERENCES:}

[1] Miyakis S, Lockshin MD, Atsumi T, Branch DW, Brey RL, Cervera R, et al International consensus statement on an Update of classification criteria for definite antiphospholipid syndrome (APS). J Thromb Haemost. 2006 Feb;4(2):295-306.

[2] Ascer E, Marques M, Gidlund M. M pneumoniae infection, pulmonary thromboembolism and antphospholipid antibodies. BMJ Case Rep. 2011 Apr 19;2011.

[3] Abuaf N, Laperche S, Rajoely B, et al. Autoantibodies to phospholipids and to the coagulation proteins in AIDS. Thromb Haemost 1997; 77: 856861 .

Disclosure of Interests: None declared

DOI: 10.1136/annrheumdis-2019-eular.3446

\section{THU0214 THE PI3K $\triangle$ SELECTIVE INHIBITOR INCB050465 ABROGATES KIDNEY PATHOLOGY IN A SPONTANEOUS MURINE MODEL OF SYSTEMIC LUPUS ERYTHEMATOSUS}

Brittany Fay, Monika Scuron, Niu Shin, Yan-Ou Yang, Eddy Yue, Andrew Combs, Eduardo Huarte, Melissa Parker, Paul Smith. Incyte Corporation, Wilmington, United States of America

Background: Systemic lupus erythematosus (SLE) is an autoimmune disease that affects multiple organs, including the skin, joints and kidneys. Though SLE typically cycles through periods of flares and remission, patients often eventually succumb to end-stage kidney or cardiovascular damage $^{1}$. SLE is characterized by the presence of autoantibodies that form immune complexes resulting in kidney deposition that significantly contribute to lupus nephritis pathogenesis. Phosphatidylinositol 3-kinases (PI3Ks) are divided into three classes (Class I, II, and III) according to their structure, regulation and substrate specificity. The Class I PI3K delta isoform (PI3K $\delta$ ) has been implicated in autoimmune diseases associated with aberrant B cell and antibody responses. INCB050465 is an oral small molecule $\mathrm{PI} 3 \mathrm{~K} \delta$ selective inhibitor currently being evaluated in clinical trials for the inflammatory indications Sjögren's syndrome and autoim mune hemolytic anaemia (NCT03627065 \& NCT03538041).

Objectives: To quantify the efficacious potential of INCB050465, a selec tive PI3K $\delta$ inhibitor, in a preclinical model of systemic lupus erythematosus with kidney pathology.

Methods: The MRL/lpr mouse model spontaneously develops multiple inflammatory phenotypes that mimic human SLE pathologies, including kidney damage resulting in proteinuria, cutaneous skin lesions and antidouble stranded DNA (anti-dsDNA) antibodies. Kidney sections were stained with hematoxylin and eosin (H\&E) and assigned a composite score based on glomerulus, crescents, protein casts, interstitial inflammation and vasculitis by a rater unaware of the treatment groups ${ }^{2}$. Flow cytometry was performed on splenocytes to characterize $B$ cell and $T$ cell subsets. Anti-dsDNA antibodies were determined by commercial ELISA.

Results: In vitro enzymatic selectivity screening revealed INCB050465 potently inhibited the PI3K $\delta$ kinase enzyme $(\mathrm{IC50}=1.1 \pm 0.5 \mathrm{nM})$, with 20,000 -fold selectivity for the other PI3K family member enzymes. Proteinuria identified spontaneous kidney damage in $85 \%+$ of vehicle treated mice by 21 weeks of age, and kidney histology revealed gross tissue enlargement associated with structural abnormalities. In contrast, therapeutic INCB050465 treatment $(0.3-3.0 \mathrm{mg} / \mathrm{kg}$, b.i.d.) dose-dependently reduced the incidence of proteinuria $(p<0.01)$, and kidney structural integrity was normalized ( $p<0.0001$ ). A feature of the MRL/lpr model is lymphocyte hyper-proliferation resulting in lymphadenopathy and splenomegaly. Therapeutic INCB050465 treatment dose-dependently reduced spleen $(p<0.01)$ and lymph node $(p<0.01)$ weight. Cutaneous skin lesions were unaffected by INCB050465 treatment. Splenocyte flow cytometry revealed no reduction in absolute lymphocyte, $\mathrm{CD}_{19^{+}} \mathrm{B}$ cell, $\mathrm{CD} 4^{+}$or $\mathrm{CD}^{+} \mathrm{T}$ cell frequencies following INCB050465 treatment. However 